\title{
WHAT IS DIFFERENT IN A CHRISTIAN MANAGER?
}

\author{
Antonio Argandoña
}

IESE Business School - University of Navarra

Av. Pearson, 21 - 08034 Barcelona, Spain. Phone: (+34) 932534200 Fax: (+34) 932534343

Camino del Cerro del Águila, 3 (Ctra. de Castilla, km 5,180) - 28023 Madrid, Spain. Phone: (+34) 913570809 Fax: (+34) 913572913 


\title{
WHAT IS DIFFERENT IN A CHRISTIAN MANAGER?*
}

\author{
Antonio Argandoña ${ }^{1}$
}

\begin{abstract}
A Christian is a person who, beyond any particular way of life or moral or spiritual practice, follows Christ. Catholic theology shows the influence that being a Christian has on a person's life. Even in today's secularized society, the Christian is seen as a person with a distinctive view of life and distinctive goals. Yet when we see the Christian as an entrepreneur or manager - i.e., engaged in the task of creating and managing companies - his outward activity seems no different from that of other, non-Christian entrepreneurs. The purpose of this paper is to understand what makes the Christian who works as an entrepreneur different, in order to try to answer the questions we may ask ourselves about the advantages and disadvantages of being a Christian.
\end{abstract}

Keywords: Catholic, Christian, Company, Entrepreneur, Manager, Work.

* Note: Presented at the 2nd International Colloquium Christian Humanism in Society and Business, Barcelona, October 24-25, 2011

${ }^{1}$ Professor of Economics, "la Caixa" Chair of Corporate Social Responsibility and Corporate Governance, IESE 


\section{WHAT IS DIFFERENT IN A CHRISTIAN MANAGER?}

\section{Introduction $^{1}$}

Given its role in satisfying consumers' needs, creating value for those who take part in it, ensuring that scarce resources are used efficiently, promoting innovation, developing nations, fostering social cohesion and furthering the common good, the business firm is a very important institution. At the same time, it is subject to criticism, including in Christian circles, to the point where business culture is condemned as "a realm of evil and idolatry, a realm that must be destroyed, rather than changed") (van Wensveen Siker 1989, p. 884). ${ }^{2}$

An institution such as the firm cannot be indifferent to religion, and especially not to the Christian religion. There are historical reasons for this, in that the earliest forms of enterprise, the predecessors of today's companies, emerged in the Middle Ages in the Christian cultural environment of the Italian city-states and the corporations of merchants created in England, the Netherlands and what is today Germany. Was it a coincidence or did religion have something to do with those initiatives? Likewise, some of the earliest studies of companies and the economic system were undertaken by philosophers and theologians, both Catholic (the School of Salamanca) and Protestant, who took up the challenge of providing economic and moral explanations for phenomena such as price discovery, international trade, trade deficits or the division of labor, in which companies played a major role (Chafuen 1992).

What concerns us here, however, is not the emergence of the modern company or the religious factors that may have influenced the ideas of company theorists. Our purpose here is to consider how the Christian religion today views the person who promotes or manages a private-sector company (with personal goals as well as a social function) that is run on capitalist lines (formed from the accumulation of capital that is pooled in order to achieve mainly economic outcomes through the production and sale of goods and services in the market). In this paper, we aim to help find answers to questions such as: Is there such a thing as a "Catholic entrepreneur" or manager? Is a Catholic entrepreneur different in any way from other entrepreneurs? Above all, should a Catholic entrepreneur be different? What do religious convictions add to the task of the entrepreneur? Do they make an entrepreneur "better" in any way? In what way?

\footnotetext{
${ }^{1}$ This paper is part of the work of the "la Caixa" Chair of Corporate Social Responsibility and Corporate Governance at IESE. I have dealt with this subject previously in Argandoña (1995, 2004a, 2007), although with different approaches from that attempted here.

2 Sirico (2000) offers some simple arguments to help understand why Catholic priests may have difficulty in understanding the world of business.
} 
This paper is intended, first and foremost, to help Catholic entrepreneurs and managers reflect on how their faith may help them in their work. In other words, it is written for the convinced. Even so, it may also be very useful for the unconvinced and for scholars of management, business ethics and related matters, to whom it may offer ideas in two directions. First, is the Catholic manager at a disadvantage to the manager who is not a Catholic? And second, can the Christian view of the manager's task help us understand what constitutes a management that is both efficient and respectful of human values?

It is not my intention to carry out a sociological, psychological or institutional study of who the Christian entrepreneur is or how he acts, nor an analysis of the situation facing Christian entrepreneurs in society today. Indeed, the image of Christians reflected in these pages may seem far removed from that of the flesh-and-blood men and women, with all their accomplishments and mistakes, who labor to take their companies forward. But neither have I attempted to depict the "ideal type" (Weber 1949) of Christian manager. In the Catholic religion, the distance between the ideal and reality is not a major problem, as it starts from the fact that $\operatorname{man}^{3}$ is a fallen creature. However, it also holds the certainty that he is called to perfection, that he has the means to achieve it and that if he really wants to he will achieve it, though not in this life. Christianity is an eminently optimistic and, at the same time, realistic religion because the distance between what "ought to be" and what "is" can always be overcome - with the help of God.

In what follows I shall try to explain, first, what distinguishes a Catholic; second, how this differentiating factor is projected in the task of the entrepreneur or manager through his work; and lastly, to what extent it is true to say that the Catholic manager is "different", or acts or should act "differently", from the non-Catholic entrepreneur or manager. I end with the conclusions.

Before we continue, there are four points I must make clear. First, I use the terms "company" and "firm" as synonymous with any activity aimed at the production of goods or services to satisfy needs, using an organizational form that tends to be privately owned and for profit, but without excluding other institutions (third sector, community purpose, etc.) or other forms of organization or management (non-profits, cooperatives, NGOs, state-owned enterprises, etc.), because there are certain common features in the promotion and management of all these activities, at least insofar as they must all be managed so as to achieve economic efficiency although this is not their only goal.

Second, I take the terms "entrepreneur" and "manager" as equivalents. Obviously, they are not, ${ }^{4}$ but the main concern here is the person whose job is to create or manage business activities.

Third, I identify "Christian" with "Catholic". This does not imply a lesser respect for other Christian confessions; it is simply a way of limiting the scope of the discussion, although some of my statements naturally also apply to other confessions. ${ }^{5}$

\footnotetext{
${ }^{3}$ In this paper, I use the word "man" to mean man and woman, as it appears in many documents of the Catholic Church, without giving it any sexist meaning.

${ }^{4}$ For an approximation to the Christian view of the entrepreneur, cf. Alford and Naughton (2001), Cornwall and Naughton (2003), Cortright and Naughton (2002), Novak (1981). On business as a vocation, cf. Chamberlain (2004), Clark (2004), Garvey (2004), Novak (1996), Sirico (2000). On the task of management, cf. Pérez López (1993), Valero and Lucas (1991), Valero and Taracena (2000).

${ }^{5}$ In particular, I do not discuss Weber's argument (1992) about Calvinist ethics and the vocation of the entrepreneur, nor the question of whether the task of the entrepreneur is a "vocation".
} 
Lastly, I support my arguments with quotations from the official documents of the Catholic Church. I realize that there may be private, more or less authorized interpretations and I will draw on them occasionally; but it is not my intention to analyze differing views on the subject at hand. Again, this does not imply a lesser respect for these private views. ${ }^{6}$ Furthermore, I have retained the actual terms used in the documents I have consulted, without attempting to "translate" a language which for many people nowadays is difficult to understand. ${ }^{7}$

\section{The Christian}

The Catechism of the Catholic Church (CCC), ${ }^{8}$ which is unquestionably an authoritative text on the subject that concerns us here, contains no precise definition of what it means to be a Christian or a Catholic. In any case, the "identity" of the Christian cannot be defined as unique. In other words, there is no single list of characteristics that define unequivocally what being a Christian consists of. This is only logical, considering that as a creature created in the image and likeness of God, who is defined as infinitely wise, full of perfections and omnipotent, each person will partially reflect these perfections to a greater or lesser degree. There are many ways of being a Christian, although they all have some traits in common (Orlandis 1998). ${ }^{9}$

To start with, we can say that a Christian is a person who "knows" something about God, namely that God exists, that he (God) created the world and that he created him, that he (God) has his own plans for the world, for humankind and for each person, and that he does not wash his hands of these realities. This knowledge of God is based on reason (CCC 36) and, above all, on faith, which is "a gift of God" (CCC 153), but also "an authentically human act [so that] trusting in God and cleaving to the truths he has revealed is contrary neither to human freedom nor to human reason" (CCC 154).

\footnotetext{
${ }^{6}$ As the reader will see, in many aspects of my interpretation of what distinguishes the Christian, especially as regards the theology of work, I am indebted to Saint Josemaria Escrivá de Balaguer, although I must emphasize that my statements on these matters are not to be attributed to him. In Argandoña (2004b, 2011), I discuss some of his ideas about work and the education of the entrepreneur.

${ }^{7}$ It is possible that this work should have engaged in dialogue with some of the sociological, political, ideological and moral trends prevailing in today's society, such as individualism, hedonism, relativism or materialism, as these currents influence the interpretation of what it is to be a Christian today, what is good or evil, or how a person should behave. I have not tried to do this, as it would have diverted me from my main concern. Yet their influence is not to be underestimated. Relativism, for example, declares that the person is incapable of knowing the truth and finding in it his freedom and the fulfillment of his deepest aspirations. For many people, religion is a consumer product, a form of entertainment or a consolation for the weak, and Christianity is often more "notional" than real, a set of traditional notions with little bearing on real life (Carrón 2011).

${ }^{8}$ The documents of the Church are cited using the following abbreviations: CA, Centesimus annus; CCC, Catechism of the Catholic Church; CV, Caritas in veritate; DCE, Deus caritas est ; GS, Gaudium et spes; LE, Laborem exercens; LG, Lumen gentium.

${ }^{9}$ We shall assume that the traits of the Christian man are known: he is a created being (i.e., he does not give himself his ultimate end, but finds it); he is a unity of body and soul; he therefore has a spiritual side (with rationality - not only instrumental but also directive rationality - and will); he has a (limited, but real) capacity to seek and find the truth and do good; he is endowed with conscience (i.e., he does not give himself the moral rule); he is free (with a freedom oriented to an end); historical (i.e., he becomes over time); relational ("unless he relates himself to others he can neither live nor develop his potential”, GS 12); open to transcendence; capable of perfection; endowed with dignity (which is inherent, not given or earned); called to an eternal life; wounded by sin ("he often does what he would not, and fails to do what he would", GS 10); and "[h]e can transcend his immediate interest and still remain bound to it" (CA 25), and so on. Insofar as this list is more realistic than, say, that of homo oeconomicus, it may help understand whether the Christian view of man has anything to add to that of neoclassical economics, for example.
} 
This faith in God leads to "a personal adherence of man to God" (CCC 150); adherence to a Person, not to an idea; only afterwards does there appear a "free assent to the whole truth that God has revealed" (CCC 150), to a creed. The Christian counts on the action of God because natural means, including human capabilities and limitations, are important but not decisive. ${ }^{10}$

How can man adhere to God if "[n]o one has ever seen God" (Jn 1:18)? Because God has taken the initiative: "In times past, God spoke in partial and various ways to our ancestors through the prophets; in these last days, he spoke to us through a son" (Heb. 1:1-2). "For a Christian, believing in God cannot be separated from believing in the One he sent (...). We can believe in Jesus Christ because He is himself God, the Word made flesh" (CCC 151). "Belief in the true incarnation of the Son of God is the distinctive sign of Christian faith" (CCC 463). ${ }^{11}$

A Christian is therefore a person who "has encountered" Jesus or, rather, who "encounters Jesus every day". "Being Christian is not the result of an ethical choice or a lofty idea, but the encounter with an event, a person, which gives life a new horizon and a decisive direction" (DCE 1). It is not, of course, a physical encounter, but nor is it an imagination or a dream. The Christian encounters Christ when he understands, through faith, that God exists and that he (God) is present in the life of the Christian and acts in him. And "Christ (...) fully reveals man to man himself and makes his supreme calling clear" (GS 22). That is to say, when the Christian "encounters" Christ, he comes to know things about himself that go beyond the natural knowledge he has of what is human; for example, that he has been created "in the image and likeness" of God (Gen. 1:26), i.e., that there is something divine in him; therefore, that he "is capable of self-knowledge, of self-possession and of freely giving himself and entering into communion with other persons" (CCC 357); and that he has been created by love, because he is "the only creature on earth which God willed for itself" (GS 24).

And in this way, he discovers that he is "called to share, by knowledge and love, in God's own life" (CCC 356). At the same time as he lives his life like other men, the Christian "reproduces" the life of Christ; his works are now, in some way, works of Christ. ${ }^{12}$ The Christian thus becomes the adoptive son of God; he experiences an "invasion" of God in his life (Polo 1996a). This does not mean that he is capable of doing superhuman things, such as walking on water or predicting the future, but that his existence is not limited to its own order of perfection. In other words, the Christian is not limited to living his own life, but also lives the life of God, who is acting in all that he does.

This "invasion" of God respects man's freedom, for "God has willed that man remain "under the control of his own decisions' (Sir. 15:14), so that he can seek his Creator spontaneously" (GS 17). Accordingly, "God's free initiative demands man's free response" (CCC 2002). The Christian must therefore strive to live in a way that is consistent with the life of Christ, who now lives and acts in him. Accordingly, there are certain behaviors that are incompatible with being a son of God, because they entail a rejection of the possibility of living the life of Christ: that is sin.

Being a Christian thus implies following a certain ethics - a set of rules, practices or commandments - and living certain virtues. But that is not enough to define the Christian,

\footnotetext{
${ }^{10}$ If God intervenes in the life of men, the dichotomies between good and evil, matter and spirit, etc., are not decisive. Good is always more fertile than evil: good "overflows" (Polo 1996a).

${ }^{11}$ And "one cannot believe in Jesus Christ without having a part in his Spirit. It is the Holy Spirit that reveals to men who Jesus is" (CCC 152). Faith in the Trinity of God is a central point of Christianity. In fact, the relationship of the Christian with God starts in his Baptism "in the name of the Father, and of the Son and of the Holy Spirit" (CCC 1272).

12 This takes place through grace, which "is a participation in the life of God" (CCC 1997).
} 
because many non-Christians do the same. Being a Christian is not mainly a way of life. ${ }^{13}$ "The first calling of the Christian is to follow Jesus" (CCC 2253) and to behave like a son of God. ${ }^{14}$ And that is achieved through love. Once again, the initiative comes from God, who "first loved us" (1 Jn 4:19) and who, in loving man, "also calls him to love, the fundamental and innate vocation of every human being" (CCC 1604). There are two dimensions to this; namely, "You shall love the Lord, your God", and "You shall love your neighbor as yourself" (Mt. 22: 37-40). That is why Christ makes love the sign of the Christian: "This is how all will know that you are my disciples, if you have love for one another" (Jn 13: 35). A Christian, therefore, is a person who loves God and others.

Love is not a vague feeling; it is recognized in works. But love is also "an extraordinary force which leads people to opt for courageous and generous engagement in the field of justice and peace (...) a force that has its origin in God" (CV 1). That is to say, the experience of the encounter with Christ contributes not only inspiration and ideas, but also capacities for action, provided by the sacraments and the others means available to Christians.

A Christian's encounter with Christ is not an intellectual encounter or the result of study, personal reflection or an inner illumination. Man is a social being who receives life through other people, learns from other people and develops with other people. Christian faith and practice come to him in the same way, i.e., through belonging to the Church. "No one can believe alone, just as no one can live alone. You have not given yourself faith as you have not given yourself life" (CCC 166). In other words, "It is in the Church (...) that the Christian fulfills his vocation. From the Church he receives the Word of God containing the teachings of "the law of Christ' (Ga 6:2)" (CCC 2030). From the Church he receives the grace of the sacraments that sustain him in the "way'. From the Church he learns the example of holiness" (CCC 2030). Christianity is learned, developed and made concrete in a community of persons, which is not a mere human organization, because Christ dwells in his Church, thus making it possible for men of all ages to encounter him.

This encounter with Christ in order to take part in his life clearly allows degrees. But the goal is excellence, or holiness: "[A]ll the faithful of Christ, of whatever rank or status, are called to the fullness of the Christian life and to the perfection of charity" (LG 40).

All the above is a necessarily partial and very poor explanation of what it is to be a Christian. Now we must apply it to the task of the manager. To do that, we need an intermediate step, which we find in work.

\section{The Christian Who Works}

"[W]ork is a fundamental dimension of man's existence on earth" (LE 4). Man, "as the "image of God' (...) is a person, that is to say, a subjective being capable of acting in a planned and rational way, capable of deciding about himself, and with a tendency to self-realization. As a

\footnotetext{
${ }^{13}$ This is an important point, especially in a relativistic society. If Christianity is limited to being a code of conduct, it will be no more valid than other alternative codes.

${ }^{14}$ From the above, it is not to be concluded that the practice of the Christian life is unimportant. On the contrary, the virtues, the practices of piety, etc., are the Christian's way of encountering Christ, of recognizing him and accepting his will, and also the means to advance in the identification with Christ. The important thing, though, is not the practices but the intention - the love - with which they are carried out.
} 
person, man is therefore the subject of work" (LE 6). We saw earlier that God has plans for man, whom he calls to a friendship, or a filial relationship, with him. And those plans include work. As we read in the first biblical stories of creation, God took man "and settled him in the Garden of Eden [the world], to cultivate and care for it” (Gen. 2:15), i.e., to work.

Through work man achieves external results that are necessary for his life and development: work produces goods to satisfy needs, develops nature, gives rise to technology (LE 5), and so on. It also brings about internal results - knowledge, capabilities, attitudes and values that the agent acquires and that perfect the agent - because "the primordial value of labor stems from man himself, its author and its beneficiary" (CCC 2428). Lastly, there are other results, which are projected onto other men: the satisfaction of other people's needs, contributions to the wellbeing of society, the development of other people's knowledge and capabilities, and so on (Pérez López 1993). Work is thus something "positive and creative, educational and meritorious" (LE 11). This can be applied to all workers, however, not just Christian workers: ${ }^{15}$ the right and duty to work and so to achieve human survival and perfection is demanded of every man.

The Christian, however, knows by faith that God has put him in the world to dominate it (Gen. 2:15). Here man receives from God, through his ancestors, the gift of the world (LE 12) and, with it, "a mandate to subject to himself the earth" (GS 34), which constitutes the core of his vocation, which he exercises through work. In work, also, there occurs that encounter of man with Christ, who came to the world to redeem it, also through work. Thus, "[b]y enduring the toil of work in union with Christ (...), man in a way collaborates with the Son of God for the redemption of humanity" (LE 27). ${ }^{16}$

The Christian, like other men and women, makes his decisions regarding the scope and content of his work based on his preferences, capabilities, history and environment. All these situations are, in principle, good, because "God saw that [the world] was good" (Gen. 1, 10, 12, 18, 21, 25, 31). Clearly, this is not to say that everything in this world is good. The important thing is that evil is not what defines the world. Obviously, like any other honest person, the Christian will exclude activities and decisions that are immoral, i.e., that may degrade him as a person. ${ }^{17}$ That is not something specifically Christian, either, because there is no reason why moral criteria should be any different for a non-Christian. ${ }^{18}$

So when it comes to making decisions about work, is it irrelevant whether a person is a Christian or not? No, it is not. First, a Christian's knowledge and human capabilities are in no

\footnotetext{
${ }^{15}$ There are also negative views of work - as the cause of alienation, for example, or as a punishment or curse, etc. However, these views do not belong to the core of the Christian tradition, at least not without proper qualification.

${ }^{16}$ Saint Josemaria Escrivá explains these various dimensions of work as follows: "Work, all work, bears witness to the dignity of man, to his dominion over creation. It is an opportunity to develop one's personality. It is a bond of union with others, the way to support one's family, a means of aiding in the improvement of the society in which we live and in the progress of all humanity. For a Christian these horizons extend and grow wider. For work is a participation in the creative work of God. When he created man and blessed him, he said: 'Be fruitful, multiply, fill the earth, and conquer it. Be masters of the fish of the sea, the birds of heaven and all living animals on the earth' (Gen. 1:28). And, moreover, since Christ took it into his hands, work has become for us a redeemed and redemptive reality. Not only is it the background of man's life, it is a means and path of holiness. It is something to be sanctified and something which sanctifies” (Escrivá de Balaguer 1973, no. 47).

17 "The moral rule tells us not only 'don't do this because it is bad', but also 'don't do what is bad because doing it makes you bad"” (Polo 1996b, 87).

${ }^{18}$ This obviously cannot be said of all ethical conceptions. The interesting point here, though, is that applying moral criteria to work-related decisions is not something that is distinctive of Christianity.
} 
way reduced by the fact of being a Christian. There are no reasons why a Christian should not know and do everything that other people know and do. The fact that work is done in a Christian way does not guarantee human success (i.e., the efficiency and profitability of work, the quality of the goods and services produced, the development of the agent's capabilities and values, etc.), but neither does it hinder success. Needless to say, a Christian cannot use immoral means; that is not a restriction, however, but a strength, assuming the aim is not to achieve an external result at any cost but to achieve external results together with the integral human development of the person and the good of others and society. ${ }^{19}$

Secondly, the Christian will have the same motivations as the non-Christian, including the pursuit of an income and the satisfaction of doing a job well or of acquiring new knowledge and capabilities; and both may act seeking the good of others - doing their best, for example, to provide a good service to a customer or to help a colleague perform a task. But if work also has a supernatural significance, this gives the Christian additional motives to do it, because "men are not deterred by the Christian message from building up the world, or impelled to neglect the welfare of their fellows, but (...) they are rather more stringently bound to do these very things" (GS 34). "We would therefore be on the wrong path if we were to disregard temporal affairs, for Our Lord awaits us there as well. (...) But we shall not attain our goal if we do not strive to finish our work well; if we do not sustain the effort we put in when we began our work with human and supernatural zeal; if we do not carry out our work as well as the best do and, if possible, (...) better than the best, because we will use all the honest human means as well as the supernatural ones which are required in order to offer Our Lord a perfect job of work, finished like filigree and pleasing in every way” (Escrivá de Balaguer 1977, no. 63).

Yet there is more. Although the Christian has no advantage when it comes to natural knowledge, he knows "something more" on the supernatural plane. If the world is the work of God, if there is an eschatological reality beyond this world, if God acts on Earth through the work of his children, then reality is "something more" than what a person who does not have faith is capable of seeing. ${ }^{20}$ "The Kingdom of God, being in the world without being of the world, throws light on the order of human society, while the power of grace penetrates that order and gives it life" (CA 25). That is to say, the Christian cannot use that enlightenment to make better technical decisions, but he can use it to make better moral decisions. Let's see how that is possible.

If they share the same natural anthropology, a Christian and a non-Christian may have the same knowledge of what is good for man. Therefore, the list of moral "duties" prepared by each may be the same, because "both for the Christian and for the non-believer the same standards of human perfection apply, because both have the same human nature and live in the same world and the same society" (Rhonheimer 1987, 923; emphasis in the original). But that is true only for a list of abstract moral "duties". In practice, the moral agent must consider these moral rules not only as theoretical knowledge but as "factually possible contents" (Rhonheimer 1987, 925; emphasis in the original), derived from "experiences and judgments about the possibilities of realizing" what is good (Rhonheimer 1987, 926). If the agent considers those duties to be not possible for him, they will cease to be duties.

\footnotetext{
${ }^{19}$ And to believe that the Christian must devote a large part of his time to spiritual activities or part of his income to charitable activities is simply a false conception of what it is to be Christian.

${ }^{20}$ We have put these statements in the conditional ("if" the world is the work of God, etc.), but for a Christian they are not mere opinions or a matter of debate; they are the truth. "Faith is certain. It is more certain than all human knowledge because it is founded on the very Word of God, who cannot lie" (CCC 157).
} 
The Christian and the non-Christian will therefore formulate different judgments about the practical possibility of performing those duties, because "the believer must possess a knowledge of what is human different from that of the non-believer" (Rhonheimer 1987, 929). Indeed, the Christian knows, through faith, things that the non-believer cannot know by natural means, such as original sin and inherited guilt (which go beyond the practical experience we may all have of the failings of humanity) and the redemption wrought by Christ. "With respect to what is human, 'salvation' means liberation from the - evident - human incapacity to fully meet the demands of what is human (...). Yet Christian revelation also teaches us that the will of God consists of ordering and integrating human perfection in divine perfection, or holiness (...) and that, therefore, there is no human perfection outside that perfection that is more than human, in accordance with the salvific divine will, which can only be known through revelation. [Revelation] also teaches us that to receive salvation and so achieve human perfection, there must be personal conversion, the mercy of God and His forgiveness, as well as saving grace. It teaches us something that is not at all obvious, namely, that suffering injustice, hunger, poverty, persecution and humiliation is not opposed to true human realization or 'happiness' (...) It reveals to us the meaning and dignity of suffering and ultimately makes us the promise that the last and definitive intervention of God in history will renew and perfect the face of the earth" (Rhonheimer 1987, 929-930; emphasis in the original).

The non-believer cannot know all this, so that "the moral demands in the sphere of what is human, accessible to every man, in many cases exceed the moral capacity of man in his fallen state and in need of redemption" (Rhonheimer 1987, 931). As Rhonheimer explains (2001), doing good often has negative consequences, which may lead to the conclusion that a morality "of the possible" is more human. An example would be when the "evils" of an unwanted pregnancy or of a failed marriage are weighed against the "goods" of unconditional respect for life or fidelity in marriage. In such cases, faced with the rift between what "must" be done and what "can" be done without suffering those undesirable consequences, a non-Christian morality may end up identifying what "must be done" with "the best that can be done". The root of the problem lies not so much in the identification of what is good for man, but in the practical judgment about whether that good can be realized. And here the difference between the point of view of the Christian and that of the non-Christian will be decisive, because the practical judgment of the Christian, who has grace, will be different.

The conclusions to be drawn from this are, it seems to me, very relevant to the subject of this paper. "The credibility, clarity and appeal of the Christian message [are founded] not on the demonstration of new or higher motivations for knowable and realizable moral demands for all men but on showing a path to overcome the divide, which is painful to any man of good will, between his (rational and autonomous) moral knowledge of the good and duty and his moral capacity" (Rhonheimer 1987, 932). "A non-Christian ethos will reduce what is Christianly obligatory to what is humanly possible and so will only incompletely detect the true possibilities of human action" (Rhonheimer 1987, 936).

"This does not mean that the moral demands of the pure human being are accessible only to the believer (...) It means that, because of the disjunction between duty and ability, this knowledge is obscured, and that whole societies may be without it (...) This means that precisely Christian morality implies the true humanism (...) compared with the various forms of non-Christian humanism, the only true humanism in the full sense is the specifically Christian humanism" (Rhonheimer 1987, 933; emphasis in the original). Benedict XVI is, in a way, more radical: "A humanism which excludes God is an inhuman humanism" (CV 78). 
In short, the Christian has, in his work, access to the same means, criteria and aids as the nonChristian. As is the case for other men and women, the purpose of his work is to achieve material and spiritual results, i.e., to satisfy needs, improve his standard of living, develop human knowledge and capabilities, serve others and society as a whole, and so on. For the Christian, however, there is a further dimension, in that man is called to a life in God, which begins in this world (through adherence to God's plan and also through work) and will continue afterwards. $^{21}$

\section{The Christian Who Creates or Manages A Company}

Based on what we have said so far, there is no work that is improper for a Christian, provided it is carried out in a way that is compatible with the encounter with God. So, is business activity an acceptable type of work for a Christian?

The answer to this question has often been "no", even among Christians, perhaps under the influence of various ideologies (Marxism, for example), or because certain attitudes, motivations and vices found in business activity are incompatible with a Christian life. ${ }^{22}$ We shall not argue with these views here, but we shall appeal to a criterion of authority: according to John Paul II, "[a] person who produces something other than for his own use generally does so in order that others may use it (...). It is precisely the ability to foresee both the needs of others and the combinations of productive factors most adapted to satisfying those needs that constitutes another important source of wealth in modern society. Besides, many goods cannot be adequately produced through the work of an isolated individual; they require the cooperation of many people in working towards a common goal. Organizing such a productive effort, planning its duration in time, making sure that it corresponds in a positive way to the demands which it must satisfy, and taking the necessary risks [which are the tasks of a manager] - all this too is a source of wealth in today's society. In this way, the role of disciplined and creative human work and, as an essential part of that work, initiative and entrepreneurial ability becomes increasingly evident and decisive. (...) Indeed, besides the earth, man's principal resource is man himself. His intelligence enables him to discover the earth's productive potential and the many different ways in which human needs can be satisfied. It is his disciplined work in close collaboration with others that makes possible the creation of ever more extensive working communities which can be relied upon to transform man's natural and human environments" (CA 32).

This long paragraph develops the arguments given earlier for the work of Christians in the world: business enterprise, like other human activities, is good and the social function of the entrepreneur and manager deserves recognition. This is not to say that there are not particular business activities (such as drug trafficking or prostitution), or particular ways of conducting business activity (e.g., based on fraud, deception or exploitation), that are incompatible with the encounter of the entrepreneur or manager with Christ in work - as there are in other professions. On this basis, the entrepreneur may develop the human quality of his activity for

\footnotetext{
${ }^{21}$ The Christian may also benefit from other aids, such as spiritual guidance and counsel; but the non-Christian also has access to such aids.

${ }^{22}$ It is not sufficient that some managers or business owners act out of morally unacceptable motives or behaviors, nor even that the majority do so; rather, it has to be proven that those motives or behaviors are a necessary and inevitable part of the nature of business activity.
} 
the satisfaction of his own and other people's needs, for his own personal development and that of those who work with him, and for the common good (Melé 2009). But this will be a challenge for both the Christian and the non-Christian manager.

However, the work of the entrepreneur also has a new dimension for the Christian, because it is part of the set of tasks of those people, the lay people, whose "special task" it is "to order and to throw light upon these affairs in such a way that they may come into being and then continually increase according to Christ to the praise of the Creator and the Redeemer" (LG 31). Its goal therefore goes beyond the mere satisfaction of human needs, wealth creation and human and social development, because "[t]he initiative of lay Christians is necessary especially when the matter involves discovering or inventing the means for permeating social, political, and economic realities with the demands of Christian doctrine and life" (CCC 899). It also provides additional motivations for working hard and well, because "[t]he knowledge that by means of work man shares in the work of creation constitutes the most profound motive for undertaking it” (LE 25).

Now it is perhaps time to answer the question that is the reason for writing this article: what or who is a Christian entrepreneur? An entrepreneur or manager is a person who works as a creator, developer or director of companies, that is to say, of production activities oriented toward the satisfaction of human needs (the needs of customers and also of owners, managers, employees, and others related to them, such as suppliers, customers, the local community, etc.) and, above all, their human, professional, social and economic development. Business enterprise is not intrinsically a cause of harm to men and women; like all human activity, it has defects, perhaps many defects, but, again like all human work and like man himself, it is redeemable.

A Christian is a man or woman who believes in God (and who comes to that knowledge of God through Jesus Christ) and adheres to him: God is not indifferent to him, just as he is not indifferent to God. He knows that God acts and has plans for him, and he seeks to collaborate in those plans. Created in the image of God and constituted as an adoptive son of God, he seeks to imitate Jesus Christ, reproducing the life of Christ in his own life. This means loving God and others. And as love has no limit, the Christian knows that he is called to excellence, i.e., to holiness. He also knows that he is a member of the Church, the community of men and women, created by Jesus. The encounter of the Christian with God takes place in the Church; in the Church he finds faith and the means to live as a Christian. The encounter of the Christian with God consists of knowing what God wants of him and trying to do it, following certain moral rules, although the decisive thing is not the code of ethics but the quest for Jesus ("Lord, what will you have me do?", Acts 9:6).

The life of a human being revolves largely around work, which is not a punishment or a curse but an expression of the dignity of man as an image of God. Through work man changes the world by producing goods to satisfy his own and others' needs; develops himself by acquiring knowledge, capabilities and virtues; and serves others. Work is a quintessentially social activity. All men work, but Christians add the dimensions that derive from being Christians, that is to say, they adhere to Christ and encounter Him in their task; seek to accomplish the will of God in their task; manifest their love of God and others; know that they are contributing to important things, such as the continuation of creation and the redemption of humanity; try to serve others, because they see in them not only people but children of God; and try to bear witness to their faith (CCC 2044). 
There is no such thing as the Christian entrepreneur or manager; there is the Christian whose job is to create or manage companies. He is expected to do what every entrepreneur must do, with the same resources. What does his being a Christian add to his task as an entrepreneur? The same as being a Christian adds to the task of any worker. He is subject to no additional restriction. In other words, he knows and can do the same as any other entrepreneur. If anything is prohibited to him, it is not because he is a Christian but because he is a person, because immoral behavior would degrade him as a person. However, his religion helps him understand the reason for these restrictions, and gives him spiritual and ascetic means to behave as he should.

Yet the Christian entrepreneur knows that he is in a "business" that goes beyond profit, efficiency or human promotion. It is the "business" of God, who has charged him with continuing the task of creation and redemption, from a privileged place - the firm - which is a key institution for the material, human and spiritual progress of persons and peoples. This gives the Christian entrepreneur a new, broader view of his task. God thus asks him to overcome "a basic feeling of weariness that obstructs the spirit in the face of ideals, so that it considers them unachievable (...), [and] a certain dullness (...) that is blind to the content of things and contents itself with superficial formalities, without going deeper" (Polo 1996, 273). In a word, the entrepreneur needs "someone to teach him to raise his sights and strive faithfully to keep his sights high" (Polo 1996, 277). That is what being a Christian adds to the entrepreneur. 


\section{References}

Alford, H. and M. J. Naughton (2001), Managing as if Faith Mattered: Christian Social Principles in the Modern Organization, Indianapolis, IN, University of Notre Dame Press.

Argandoña, A. (1995), "El empresario cristiano y su función en la construcción de la sociedad", in El empresario: Razones para la esperanza, Valencia, Instituto Social Empresarial.

Argandoña, A. (2004a), "What does being a Catholic add to a business vocation?", IESE Occasional Paper 04/5-E, 2004.

Argandoña, A. (2004b), "El trabajo según las enseñanzas de San Josemaría Escrivá. Una reflexión desde la perspectiva de las actuales corrientes económicas y sociológicas", in J. Borobia, M. Lluch, J. I. Murillo and E. Terrassa (eds.), Trabajo y espiritu, Pamplona, Eunsa, pp. 301-330.

Argandoña, A. (2007), "La identidad cristiana del directivo de empresa", in A. Aranda (ed.), Identidad cristiana. Coloquios universitarios, Pamplona, Eunsa, pp. 383-404.

Argandoña, A. (2011), “Josemaría Escrivá de Balaguer y la misión del IESE en el mundo de la empresa”, Scripta et Documenta, 5, pp. 131-162.

Carrón, J. (2011), ¿Qué significa ser cristiano hoy? Madrid, Encuentro.

Chafuen, A. A. (1992), Faith and Liberty. The Economic Thought of the Late Scholastics, Lanham, MY, Lexington Books.

Chamberlain, G. L. (2004), “The evolution of business as a Christian calling”, The Review of Business, 25, 1, pp. 27-36.

Clark, C. M. A. (2004), "Bringing realism to management education: Contributions from Catholic social thought”, The Review of Business, 25, 1, pp. 6-14.

Cornwall, J. R. and M. J. Naughton (2003), "Who is the good entrepreneur? An exploration within the Catholic social tradition", Journal of Business Ethics, 44, pp. 61-75.

Cortright, S. A. and M. J. Naughton (eds.), (2002), Rethinking the Purpose of Business: Interdisciplinary Essays Within the Catholic Social Tradition, Indianapolis, IN, University of Notre Dame Press.

Escrivá de Balaguer, J. M. (1968), Conversaciones con Mons. Escrivá de Balaguer, Madrid, Rialp.

Escrivá de Balaguer, J. M. (1973), Es Cristo que pasa, Madrid, Rialp.

Escrivá de Balaguer, J. M. (1977), Amigos de Dios, Madrid, Rialp.

Garvey, G. E. (2004), "Business as a vocation: Implications for Catholic legal education”, The Review of Business, 25, 1, pp. 37-44.

Melé, D. (2009) Business Ethics in Action. Seeking Human Excellence in Organizations, Houndmills, Palgrave Macmillan. 
Novak, M. (1981), “A theology of the corporation”, in M. Novak and J. W. Cooper, (eds.), The Corporation. A Theological Inquiry, Washington DC, American Enterprise Institute for Public Policy Research, pp. 203-224.

Novak, M. (1996), Business as a Calling: Work and the Examined Life, New York, NY, Free Press.

Orlandis, J. (1998), ¿Qué es ser católico? Pamplona, Eunsa.

Pérez López, J. A. (1993), Fundamentos de la dirección de empresas, Madrid, Rialp.

Polo, L. (1996a), “Acerca de la plenitud”, in L. Polo, Sobre la existencia cristiana, Pamplona, Eunsa, pp. 271-288.

Polo, L. (1996b), Ética. Hacia una versión moderna de los temas clásicos, Madrid, Unión Editorial.

Rhonheimer, M. (1987), "Moral cristiana y desarrollo humano. Sobre la existencia de una moral de lo humano específicamente cristiana", in A. Sarmiento, T. Rincón, J. M. Yanguas, A. Quirós (ed.), La misión del laico en la Iglesia y en el mundo. VIII Simposio Internacional de Teología de la Universidad de Navarra, Pamplona, EUNSA, pp. 919-938

Rhonheimer, M. (2001), "Is Christian morality reasonable? On the difference between secular and Christian humanism", Annales Theologici, 15, 2, pp. 529-549.

Rodríguez, P. (1987), Vocación, trabajo, contemplación. Pamplona, Eunsa, 2nd ed.

Sirico, R. A. (2000), “The entrepreneurial vocation”, Journal of Markets \& Morality, 3, 1, pp. 1-21.

Valero, A. and J. L. Lucas (1991), Politica de empresa. El gobierno de la empresa de negocios, Pamplona, Eunsa.

Valero, A. and E. Taracena (2000), La empresa de negocios y la alta dirección. Procedimientos politicos de gobierno, Pamplona, Eunsa.

van Wensveen Siker, L. (1989), “Christ and business: A typology for Christian business ethics”, Journal of Business Ethics, 8, pp. 883-888.

Weber, M. (1949), "Objectivity in social science and social policy”, in The Methodology of the Social Sciences, New York, NY, Free Press (original 1904).

Weber, M. (1992), The Protestant Ethic and the Spirit of Capitalism, London, Routledge (original 1904-1905). 


\section{Documents of the Catholic Church}

CA - John Paul II, Encyclical Letter Centesimus annus, May 1, 1991.

http://www.vatican.va/holy_father/john_paul_ii/encyclicals/documents/hf_jpii_enc_01051991_centesimus-annus_en.html.

CCC - Catechism of the Catholic Church.

http://www.vatican.va/archive/ENG0015/_INDEX.HTM.

CV - Benedict XVI, Encyclical Letter Caritas in veritate, June 29, 2009.

http://www.vatican.va/holy_father/benedict_xvi/encyclicals/documents/hf_benxvi_enc_20090629_caritas-in-veritate_en.html.

DCE - Benedict XVI, Encyclical Letter Deus caritas est, December 25, 2005.

http://www.vatican.va/holy_father/benedict_xvi/encyclicals/documents/hf_ben-

xvi_enc_20051225_deus-caritas-est_en.html

GS - Second Vatican Ecumenical Council, Pastoral Constitution Gaudium et spes, December 7, 1965.

http://www.vatican.va/archive/hist_councils/ii_vatican_council/documents/vat-

ii_cons_19651207_gaudium-et-spes_en.html

LE - John Paul II, Encyclical Letter Laborem exercens, September 14, 1981.

http://www.vatican.va/holy_father/john_paul_ii/encyclicals/documents/hf_jp-

ii_enc_14091981_laborem-exercens_en.html

LG - Second Vatican Ecumenical Council, Dogmatic Constitution Lumen gentium, November $21,1964$.

http://www.vatican.va/archive/hist_councils/ii_vatican_council/documents/vat-

ii_const_19641121_lumen-gentium_en.html 